\title{
PERSEPSI MAHASISWA IMENGENAI DAMPAK PENERAPAN METODE PEMBELAJARAN DOSEN (Studi Pada Jurusan Pendidikan Agama Islam Falkultas Tarbiyah dan Keguruan UIN Alauddin Makassar)
}

\author{
Erwin Hafid \\ Fakultas Tarbiyah dan Keguruan UIN Alauddin Makassar \\ Email: erwinhaf@gmail.com \\ Bahraeni \\ Fakultas Tarbiyah dan Keguruan UIN Alauddin Makassar \\ Email: bahraeni.tarbiyah@uin-alauddin.ac.id \\ Usman \\ Fakultas Tarbiyah dan Keguruan UIN Alauddin Makassar \\ Email: usman.tarbiyah.@uin-alauddin.ac.id
}

\begin{abstract}
This paper is the result of research that is motivated by the importance of majors at universities to know the quality of lecturers learning after the learning activities take place by looking at the perception of students. This study describes the impact of the impact of the application of lecturer teaching methods at the Department of Islamic Education Faculty of Tarbiyah and UGM Teachers Alauddin Makassar. This research is located at UIN Alauddin Makassar with research population all students of Department of Islamic Education Faculty of Tarbiyah and Teacher Training UIN Alauddin Makassar. The result of the research shows that the impact of the application of lecturer's teaching method at the Department of Islamic Education Faculty of Tarbiyah and Teacher Training UIN Alauddin Makassar can be seen through several forms: (a) easy to reach the learning goal $65.26 \%$ agreeing (Good category); (b) easy to understand learning materials $75.79 \%$ agreed (Good category); (c) effectively achieve learning objectives $80 \%$ agree (excellent category); (d) increase student learning motivation $77.89 \%$ agreed (good category); (e) increase student interest $80 \%$ agree (good category); $(f)$ create an active learning atmosphere $83.16 \%$ agree (excellent category); $(g)$ create an interesting learning atmosphere of $75.79 \%$ (Good category); $(h)$ create a fun learning atmosphere $80 \%$ agree (Good category); (i) establishing students' familiarity $74.74 \%$ agreeing (Good category); (j) build positive communication between students and lecturers $81.05 \%$ agreed (very good category); ( $k$ ) build a religious attitude $80 \%$ students agree (good category); (l) to form social attitudes $89.47 \%$ students agree (very good category); (m) form emotional attitudes of students $69.47 \%$ agreed (Good category).
\end{abstract}

Keywords: Perception, Learning Method, Lecturer 


\section{PENDAHULUAN}

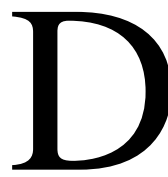
osen, dalam proses pembelajaran memiliki peran yang sangat penting karena sehebat apapun kemajuan sains dan teknologi peran dosen akan selalu diperlukan. Jauh lebih penting dalam memenuhi tuntutan ini maka dosen diharapkan mampu memaknai pembelajaran serta menjadikan pembelajaran sebagai ajang pembentukan kompetensi dan perbaikan kulalitas peribadi mahasiswa, Menurut Mulyasa (2006: 24) pendidik harus memacu diri dalam pembelajaran dengan memberikan kemudahan belajar bagi seluruh peserta didik agar dapat mengembangkan potensinya secara optimal dan menyenangkan dengan memposisikan diri secara konkrit.

Profesi yang disandang oleh seorang dosen (Profesionalme dosen) berarti suatu pekerjaan yang membutuhkan pengetahuan, keterampilan, kemampuan keahlian dan ketelatenan untuk menjadikan mahasiswa memiliki perilaku sesuai dengan yang diharapkan. Russel Pate melihat profesi merupakan simbol dari suatu pekerjaan yang selanjut menjadi pekerjaan itu sendidri. Profesioanal juga diartikan sebagai suatu keterampilan teknis yang dimiliki oleh seseorang yang didukung oleh keahlian, rasa tanggung jawab dan rasa kejawatan. Dengan demikian profesi dosen setidaknya memiliki beberapa kemampuan teknis dan keterampilan khusus untuk mendidik para mahasiswa.

Salah satu bagian penting yang diharapkan menjadi pertimbangan dasar dosen dalam menjalankan tugas profesinya adalah pemilihan dan penerapan metode pembelajaran. Metode pembelajaran ialah cara yang dipergunakan guru dalam mengadakan hubungan dengan peserta didik pada saat berlangsungnya pengajaran (Sudjana, 2005: 76). Metode pembelajaran juga dapat diartikan sebagai rencana yang sistematis untuk menyampaikan informasi (Gerlach dan Elly, 80:14). Dengan demikian, metode pembelajaran merupakan jalan yang ditempuh dalam rangka memberikan sebuah pemahaman terhadap peserta didik tentang pelajaran yang sedang dipelajarinya.

Metode sangat penting dalam pembelajaran diharapkan dimiliki dan dikuasai oleh seorang dosen sebelum memasuki ruang pembelajaran. Metode sangat berpengaruh besar dalam pembelajaran, dengan metode materi mudah dipahami dan dangan metode pula pembelajaran bisa sukses atau gagal. Kebanyakan seorang pendidik yang menguasai materi dengan baik, akan tetapi bisa gagal dalam pembelajaran disebabkan tidak mendapatkan metode yang tepat untuk memahamkan peserta didiknya.

Metode pembelajaran juga sangat berperan penting dalam pendidikan, karena metode merupakan pondasi awal untuk mencapai suatu tujuan pendidikan dan asas keberhasilan sebuah pembelajaran. Pada dasarnya pemerintah sudah menetapkan aturan-aturan dengan memberikan jadwal-jadwal pelajaran yang telah disepakati 
melalui penetapan kurikulum nasional yang dikembangkan dengan mata pelajaran muatan lokal.

Pada intinya metode yang digunakan oleh para pendidik termasuk dosen dalam perguruan tinggi diharapkan hasilnya akan berdampak pada mutu pendidikan yang baik, jika metode yang digunakan tidak bermutu maka hasilnya pun akan berakibat pada mutu pembelajaran yang dikelolanya. Dengan demikian, seorang pendidik harus memberikan perhatian penuh kepada metode yang ingin digunakan dalam pembelajaran.

Sehunbungan dengan hal di atas, maka peneliti tertarik melakukan penelitian dalam kaitannya penerapan metode pembelajaran dosen dengan fokus pada kajian "Persepsi Mahasiswa Mengenai Dampak Penerapan Metode Pembelajaran Dosen (Studi Pada Jurusan Pendidikan Agama Islam Fakultas Tarbiyah dan Keguruan UIN Alauddin Makassar)".

\section{KAJIAN TEORETIS}

\section{A. Teori Persepsi}

1. Pengertian

Secara etimologis, persepsi dalam bahasa Inggris perception berasal dari bahasa latin perception; dari percipere yang artinya menerima atau mengambil. Kata "persepsi" biasanya dikaitkan dengan kata lain, seperti dalam ilmu sosial digunakan persepsi diri, persepsi sosial (Calhoun \& Aroucella, 1990; Sarwono, 1997, Gerungan, 1987), dan persepsi interpersonal (Rakhmat, 1991). Istilah yang banyak digunakan adalah social perception.

Menurut Muhadjir (1992: 81), keragaman stimulus dengan objek pribadi atau orang, dipelajari oleh banyak ahli. ada yang memilih orang sebenarnya (Sherman) fotonya (Allport), filmnya (Cline), gambar diagram orang (Thitchener), dan suara orang (Davits). Sementara studi meragamkan suara emosionalnya dengan isi yang sama (Horowitz), yang lain membuat sebaliknya (Soskin).

Persepsi (perception) dalam arti sempit ialah penglihatan, bagaimana cara seseorang melihat sesuatu; sedangkan dalam arti luas ialah pAndangan atau pengertian, yaitu bagaimana seseorang memAndang atau mengartikan sesuatu (Sobur, 2011: 445). Persepsi juga dipAndang sebagai proses seseorang menjadi sadar akan segala sesuatu dalam lingkungannya melalui indera-indera yang dimilikinya (Gulo, 1982: 207).

Dengan demikian, persepsi merupakan pengalaman tentang objek, peristiwa, atau hubungan-hubungan yang diperoleh dengan menyimpulkan informasi dan menafsirkan pesan. 


\section{Proses Persepsi}

Salah satu pandangan yang dianut secara luas dalam ilmu psikologi, sebagai telaah ilmiah, berhubungan dengan unsur dan proses merupakan perantara rangsangan di luar organisme dengan tanggapan fisik arganisme yang dapat diamati terhadap rangsangan. Menurut rumusan ini, yang dikenal dengan teori rangsangan-tanggapan (stimulus S/R), persepsi merupakan bagian dari keseluruhan proses yang menghasilkan tanggapan setelah rangsangan diterapkan kepada manusia. Subproses psikologis lainnya yang mungkin adalah pengenalan, perasaan, dan penalaran. Persepsi dan kognisi diperlukan dalam semua kegiatan psikologis. Bahkan, diperlukan bagi orang yang paling sedikit terpengaruh atau sadar akan adanya rangsangan menerima dan dengan suatu cara menahan dampak dari rangsangan. Proses persepsi dapat dilihat melalui Gambar 2.1.

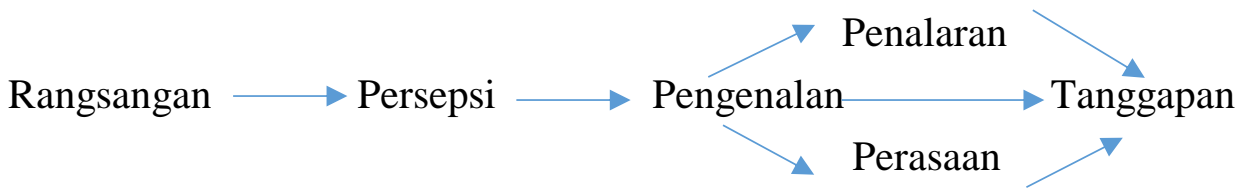

Bagan 2.1 Variabel Psikologis di antara Rangsangan dan Tanggapan (Sobur, 2011: 447).

Rasa dan nalar bukan merupakan bagian yang perlu dari setiap situasi rangsangantanggapan, sekalipun kebanyakan tanggapan individu yang sadar dan bebas terhadap satu rangsangan atau terhadap satu bidang rangsangan sampai tingkat tertentu dianggap dipengaruhi oleh akal atau emosi, atau kedua-duanya.

Persepsi, pengenalan, penalaran, dan perasaan kadang-kadang disebut variabel psikologis yang muncul di antara rangsangan dan tanggapan. Sudah tentu ada pula cara lain untuk mengonsepsikan lapangan psikologi, namun rumus S-R dikemukakan di sini karena telah diterima secara luas oleh para psikolog dan karena unsur-unsur dasarnya mudah dipahami dan digunakan oleh ilmu sosial lainnya. (Hannessy, 1981:117)

Dalam kajian psikologi dikatakan bahwa tingkah laku seseorang, harus merupakan fungsi dari cara dia memAndang. Oleh karena itu untuk mengubah tingkah laku seseorang, harus dimulai dari mengubah persepsinya. Dalam proses persepsi, terdapat tiga komponen utama yakni:

a. Seleksi, merupakan proses penyaringan oleh indera terhadap rangsangan dari luar, intensistas dan jenisnya dapat banyak atau sedikit.

b. Interpretasi, yaitu proses mengorganisasikan informasi sehingga mempunyai arti bagi seseorang. Interpretasi juga bergantung pada kemampuan seseorang untuk 
mengadakan pengkategorian informasi yang diterimanya, yaitu proses mereduksi informasi yang kompleks menjadi sederhana.

c. Interpretasi dan persepsi emudian diterjemahkan dalam bentuk tingkah laku seagai reaksi (Depdikbud, 1985, dalam Sobur, 2011: 447). Jadi, proses persepsi adalah melakukan seleksi, interpretasi, dan pembulatan terhadap informasi yang sampai.

Bagi hampir semua orang, sangatlah mudah untuk melakukan perbuatan melihat, mendengar, membau, merasakan, dan menyentuh yakni proses-proses yang sudah semestinya ada. Namun, informasi yang datang dari organ-organ indera perlu terlebih dahulu diorganisasikan dan diinterpretasikan sebelum dapat dimengerti dan proses ini dinamakan persepsi (Hardy dan Heyes dalam Sobur, 2011: 448). Tidak semua informasi yang masuk ke organ indera pada suatu waktu dirasakan secara sadar.

Sebagai contoh, misalnya Anda tidak memperhatikan semua pesan yang datang dari organ-organ indera di kulit Anda, yaitu berupa tekanan pakaian yang Anda pakai terhadap kulit Anda. Apabila Anda mengonsentrasikan secara penuh semua suara yang masuk ke telinga Anda beberapa saat, berarti Anda memperhatikan suara-suara yang ada pada saat itu dan tidak merasakan secara sadar adanya tekanan melalui pakaian pada kulit.

Persepsi telah menarik perhatian para filsuf dan psikolog mereka menjelaskan bahwa manusia secara alamiah ingin mengetahui dunia di luar dirinya dan seberapa tepat mereka menggambarkannya. Pengalaman tersebut sangat bergantung pada alat indera yang terdiri atas retina mata dan saraf sensorik yang menghubungkan retina dengan area visual cortex. Ketika cahaya lampu mengenai mata, kita menangkap warnawarna. Ketika gelombang suara sampai ke telinga, kita mendengar nada. Tanpa alat indera tidak ada kontak dengan dunia luar (Corner dan Hawthorn, 1985, dalam Zulfebriges, 1995).

Persepsi dialami oleh manusia, berawal dari alat sensor plus secara seseorang memperoleh informasi yang diterimanya. William James, psikolog terkenal dari Amerika, menyatakan: "Part of what we perceive come through the sense from the object before us; another part always comes....out of ouwn head (Morga, 1961).

Meskipun banyak stimulus berbeda-beda yang sampai kepada kita tentang masalah yang sama, apa yang bisa kita hayati adalah terbatas pada saat-saat tertentu. Apa yang kita hayati tidak hanya bergantung pada stimulus, tetapi juga pada proses kognitif yang merefleksikan minat, tujuan, da harapa seseorang pada saat itu pemusatan persepsi ini disebut "perhatian" (Sobur, 2011: 449).

Perhatian mempunyai fungsi memiliki dan mengarahkan rangsangan-rangsangan yang sampai kepada kita, sehingga tidak kita terima secara kacacu. Perhatian dipengaruhi oleh beberapa faktor yang dapat dibagi dalam dua golongan besar, yaitu 
faktor luar dan faktor dalam. Faktor luar adalah faktor-faktor yang terdapat pada objek yang diamati itu sendiri yaitu intensitas atau ukuran, kontraks pengulangan, dan gerakan; sedangan faktor dalam adalah faktor-faktor berasal dari dalam diri individu si pengamat yaitu, motif kesediaan dan harapan (Dirgagunarsa, 1996:107).

Persepsi itu bersifat kompleks, tidak ada hubungan satu lawan satu antara pesan yang terjadi di "luar sana". Mempelajari bagaimana dan mengapa pesan pesan ini berbeda sangat penting memahami komunikasi. Kita dapat mengilustrasikan bagaimana persepsi bekerja dengan menjelaskan tiga langkah yang terlibat dalam sebuah proses. Tahap-tahap ini tidaklah saling terpisah satu sama lainnya. Kenyataannya, ketiganya bersifat kontinu, bercampu baur dan bertumpang tindih satu sama lainnya sebagaimana Gambar 2.2.

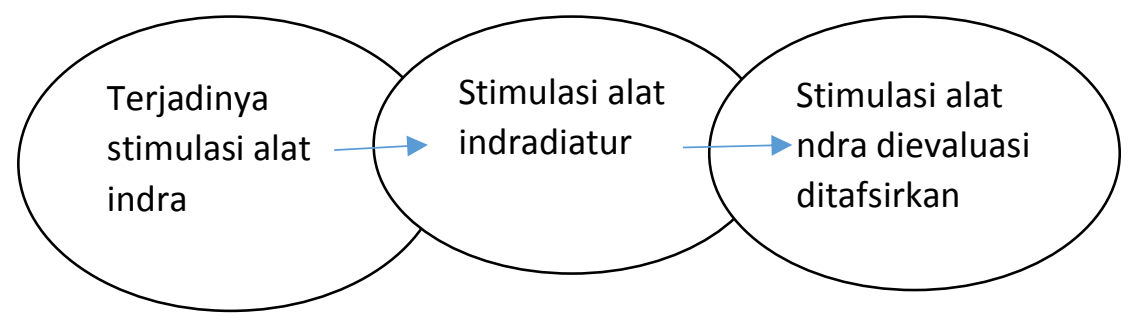

Gambar 2.2. Proses Persepsi (De Vito, 1997 dalam Sobur, 2011: 449)

\section{B. Metode Pembelajaran}

Salah satu usaha yang tidak pernah ditinggalkan guru dan praktisi pembelajaran adalah bagaimana memahami kedudukan metode sebagai salah satu komponen yang ikut ambil bagian bagi keberhasilan pembelajaran. Paling tidak, berdasarkan berbagai analisis metode berkedudukan penting dalam dunia pembelajaran, karena berbagai alasan:

1. Metode sebagai alat motivasi ekstrinsik, metode menempati peranan yang tidak kalah petingnya dari komponen lalinnya dalam kegiatan belajar mengajar. Tidak ada satupun kegiatan belajar mengajar yang tidak menggunakan metode pembelajaran. Ini berarti guru memahami benar kedudukan metode sebagai alat motivasi ekstrinsik dalam kegiatan belajar mengajar. Motivasi ekstrinsik adalah motif-motif yang aktif dan berfungs karena adanya perangsang dari luar (Sardiman, 1988; 90). Karena itu, metode berfungsi sebagai alat perangsang dari luar yang dapat membangkitkan belajar seseorang.

2. Metode sebagai strategi pengajaran, dalam kegiatan belajar mengajar tidak semua peserta didik mampu berkonsentrasi dalam waktu yang relative lama. Daya serap peserta didik terhadap bahan yang diberikan juga bermacam-macam, ada yang cepat, ada yang sedang, dan ada yang lambat. Faktor intelegensi mempengaruhi daya serap peserta didik terhadap bahan pembelajaran yang diberikan oleh guru. 
Cepat lambatnya penerimaan peserta didik terhadap bahan pembelajaran yang diberikan menghendaki pemberian waktu yang bervariasi, sehingga penguasaan penuh dapat tercapai.

3. Metode sebagai alat untuk mencapai tujuan. Tujuan adalah suatu cita-cita yang akan dicapai dalam kegiatan pembelajaran. Tujuan merupakan pedoman yang memberi arah kemana kegiatan pembelajaran akan dibawa oleh guru/pendidik.

Secara umum metode pembelajaran yang lazim digunakan meliputi:

1. Metode Ceramah

Metode ceramah merupakan cara penyajian atua penyampaian imformasi pembelajran melalui penerangangan atau penuturan secara lisan oleh guru terhadap siswa. Metode ini sering juga disebut metode kuliah, sebab guru mengajar dalam bentuk memberikan kuliah kepada peserta didik (Daradjat, dkk., 2011: 289).

Langkah-langkah pelaksanaan metode ceramah meliputi: (1) persiapan ceramah, (2) penyajian ceramah, (3) generelisasi, (4) aplikasi penggunaan. Metode ceramah wajar dilaksanakan apabila:

a. Jumlah murid terlampau banyak sehingga sulit menyampaikan dengan metode lain

b. Bahan yang disampaikan merupakan topik yang baru yang mengandung imformasi penjelasan atau uraian

c. Tidak ditemui bahan yang disanpikan itu dalam buku yang dipergunakan oleh murid sebagai buku pedoman

d. Guru seorang pembicara yang mahir dan bersemangat dan dapat di tarik serta memasang perhatian murid

e. Guru menyimpulka dari pokok-pokok yang penting dari ceramah yang diberikan

f. Bahan yang harus di ajarkan banyak sekali sedangkan waktu terbatas

g. Dalam memberikan gambaran/ilustrasi terhadap bahan pelajaran dan kata-kata tertentu.

\section{Metode diskusi}

Kata diskusi berasal dari bahas latin yaitu discuss berarti memeriksa, menyelidik. Dengan demikian, metode diskusi yaitu cara penyajian/penyampaian bahan pembelajaran dimana guru memberikan kesempatan kepada peserta didik atau kelompok untuk mengadakan pembicaraan ilmiah guna mengumpulkan pendapat, membuat kesimpulan. Metode diskusi merupakan cara penyajian/penyampaian bahan pembelajaran, dimana pendidik memberikan kesempatan kepada para peserta didik/kelompok-kelompok peserta didik untuk mengadakan pembicaraan ilmiah guna mengumpulkan pendapat, membuat kesimpulan atau menyusun berbagai alternative pemecahan atas sesuatu masalah (Yurmaini dalam Ramayulis, 2014: 467). 
Bentuk-bentuk diskusi dalam pembelajaran dapat dikelompokkan: (1) The social problem meeting (para peserta didik berbincang-bincang memecahkan masalah sosial dalam kelasnya), (2) The open ended meething (memecahkan masalah yang hubungannya dengan kehidupan mereka sehari-hari), (3) The educational diagnosis (memcahkan masalah mengenai pelajaran dikelas dengan maksud saling mengoreksi pemahaman mereka).

Langkah-langkah mengguanakan metode diskusi: (1) guru mengemukakan masalah yang akan didiskusikan, memberikan pengarahan, (2) membentuk kelompok diskusi, mengatur tempat duduk, ruangan, (3) guru berkeliling dari kelompok yang satu kelompok yang lain, (4) kemudian tiap kelompok diskusi melaporkan hasil diskusinya, (5) peserta didik mencatat hasil diskusi dan guru mengumpulkan laporan hasil diskusi tersebut, (6) mengadakan tindak lanjud diskusi.

\section{Metode tanya jawab}

Metode tanya jawab adalah cara guru mentransformasikan materi pelajaran melalui tanya jawab. Metode tanya jawab juga diartikan sebagai suatu cara mengajar dimana seorang pendidik mengajukan beberapa pertanyaan kepada peserta didik tentang bahan pelajaran yang diajarkan atau telah diajarkan atau bahan yang telah mereka baca sambil memperhatikan proses berpikir di antara peserta didik (I Bola, dkk dalam Ramayulis, 2014: 451).

Pertanyaan-peranyaan yang diharapkan terbangun melalui metode tanya jawab hendaknya memperhatikan ranah Taksonomi Bloom. Terdapat 6 macam pertanyaan yang baik untuk dijadikan pedoman tanya-jawab yaitu: (1) pertanyaan mengenai ingatan, memori, atau hafalan; (2) pertanyaan untuk mengecek pemahaman; (3) pertanyaan mengenai penerapan; (4) pertanyaan analisis; (5) pertanyaan kemampuan berfikir kreatif atau sintesis; (6) pertanyaan bersifat penilaian atau evaluatif yang dilakukan di akhir.

\section{Metode demonstrasi}

Metode demonstrasi adalah cara pembelajaran dengan memperagakan atau mempertunjukkan sesuatu di hadapan peserta didik untuk memperjelas pengertian, misalnya cara shalat, tayamum, dan lain-lain. Istilah demonstrasi dalam pembelajaran dipakai untuk menggambarkan suatu cara mengajar yang pada umumnya penjelasan verbal dengan suatu kerja fisik atau pengoperasian peralatan barang atau benda. Pendidik mempertunjukkan sambil menjelaskan tentang sesuatu yang didemonstrasikan (Ramayulis, 2014: 459). 
Langkah-langka penerapannya: (1) perumusan tujuan yang inigin didemonstrasikan; (2) menetapkan garis besar langkah demonstrasi; (3) mempertimbangkan waktu; (4) pertimbangkan kemampuan guru; (5) pertimbangkan alat yang digunakan; (6) tetapkan rencana penilaian.

\section{Metode pemberian tugas}

Metode pemberian tugas atau resitasi merupakan suatu cara dalam proses belajar mengajar, dimana guru memberi tugas tertentu dan siswa mengerjakannya, kemudian tugas tersebut dipertanggungjawabkan kepada guru. Syarat-syarat pemberian tugas: (1) tugas yang diberikan harus berkaitan dengan pelajaran yang telah mereka pelajari; (2) guru harus dapat mengukur dan memperkirakan bahwa tugas yang diberikan kepada siswa akan dapat dilaksanakannya sesuai dengan kesanggupan dan kecerdasan yang dimilikinya; (3) guru harus menanamkan kepada siswa bahwa tugas yang diberikan kepada mereka akan dikerjakan atas kesadaran sendiri yang timbul dari hati sanubarinya; (4) jenis tugas yang diberikan kepada siswa harus dimengerti siswa, sehingga tidak ada keraguan dalam melaksanakannya.

Metode pemberian tugas bertujuan untuk melatih para siswa untuk bertanggung jawab terhadap tugasnya, menanamkan rasa responsibility terhadap proses pembelajaran, melatih psikomotorik dan keterampilan tertentu, menanamkan kebiasaan belajar tanpa diberi tugas, tekun dan semangat belajar untuk masa depan.

\section{Metode eksperimen}

Metode eksperimen digunakan apabila peserta didik melakukan sesuatu percobaan, setiap roses dan hasil percobaan itu diamati oleh setiap peserta didik (Ramayulis, 2014: 463). Metode eksperimen ini banyak dipakai orang semenjak zaman dahulu. Hasil-hasil penemuan baru banyak didapatkan melalui metode eksperimen.

Dalam sebuah riwayat, pada suatu hari Nabi Muhammad saw sedang berada dalam masjid, tiba-tiba masuklah seorang laki-laki shalat. Kemudian ia menghadap Nabi seraya memberi salam. Setelah Nabi menjawab salamnya lalu ia berkata: kembalillah dan shalatlah sekali lagi, karena engkau belum shalat. Kemudian laki-laki itu shalat sekali lagi, setelah selesai ia dating menghadap Nabi seraya memberi salam. Nabi saw bersabda: kembalillah dan shalat sekali lagi, karena engkau belum shalat (hal ini sampai tiga kali).

Kemudian berkata laki-laki itu: demi Allah, saya tidak pandai mengerjakan shalat selain daripada itu, sebab itu ajarkanlah aku. Nabi saw bersabda: apabila engkau berdiri hendak mengerjakan shalat, hendaklah takbir, kemudian bacalah apa yang mudah bagi engkau di antara al-Qur'an, sudah itu ruku'lah hingga tenang dalam ruku' itu, kemudian 
bangkitlah hingga lurus kembali, kemudian sujudlah hingga tenang dalam sujud itu, kemudian bangkitlah sehingga tenang dalam duduk, kemudian sujudlah kembali dan seterusnya (HR. Bukhari) dalam (Ramayulis, 2014: 463).

\section{HASIL PENELITIAN}

Secara umum pelaksanaan pembelajaran pada Jurusan Pendidikan Agama Islam Fakultas Tarbiyah dan Keguruan UIN Alauddin Makassar diklasifikasi melalui 2 (dua) tahapan kegiatan yang disebut istilah semester ganjil dan genap pada setiap tahun berjalan. Pada kegiatan penelitian ini berjalan, berlangsung kegiatan pembelajaran semester genap TA. 2016/2017.

Persepsi mahasiswa mengenai dampak penerapan metode pembelajaran dosen pada Jurusan Pendidikan Agama Islam Fakultas Tarbiyah dan Keguruan UIN Alauddin Makassar dapat diklasifikasi sebagai berikut:

a. Hasil Belajar

Hasil belajar sebagai dampak penerapan metode pembelajaran dosen dapat dilihat dalam bentuk: (1) mudah mencapai tujuan; (2) mudah memahami materi; (3) efektif mencapai tujuan. Secara rinci deskripsi terhadap ketiga ini dapat dilihat sebagai berikut:

Persepsi mahasiswa sebagai dampak penerapan metode pembelajaran dalam bentuk mudah mencapai tujuan dapat dilihat melalui Tabel 3.1.

Tabel 3.1 Mudah Mencapai Tujuan Pembelajaran

\begin{tabular}{|c|c|c|c|c|}
\hline No. & Kriteria Persepsi & Frekuensi & Persentase & Ket. \\
\hline 1. & Sangat Sesuai & 35 & 36.84 & $\mathrm{SB}$ \\
\hline 2. & Sesuai & 27 & 28.42 & B \\
\hline 3. & Kurang Sesuai & 24 & 25.26 & $\mathrm{~KB}$ \\
\hline 4. & Tidak Sesuai & 9 & 9.47 & TB \\
\hline \multicolumn{2}{|r|}{ Jumlah } & 95 & 100 & \\
\hline
\end{tabular}

Sumber: Angket Nomor 6-7.

Tabel 3.1 di atas menggambarkan bahwa metode pembelajaran dosen memiliki dampak dalam bentuk mudah mencapai tujuan pembelajaran 62 orang atau $65.26 \%$ menyatakan setuju, sementara yang tidak setuju 33 orang atau $34.74 \%$. Dengan demikian secara umum dampak pembelajaran dosen menurut persepsi mahasiswa dipandang mudah mencapai tujuan pembelajaran, namun demikian masih ada mahasiswa yang menyatakan sebaliknya (tidak dapat mencapai tujuan pembelajaran). Jika dikonfirmasi berdasarkan kriteria yang telah disusun peneliti, maka didapatkan data 35 (36.84\%) memiliki persepsi kategori sangat baik, 27 (28.42\%) memiliki persepsi kategori baik, 24 (25.26\%) memiliki persepsi kategori kurang baik, dan 9 (9.47\%) memiliki persepsi 
kategori tidak baik.

Persepsi mahasiswa sebagai dampak penerapan metode pembelajaran dalam bentuk mudah memahami materi pembelajaran dapat dilihat melalui Tabel 3.2.

Tabel 3.2 Mudah Memahami Materi Pembelajaran

\begin{tabular}{|c|c|c|c|c|}
\hline No. & Kriteria Persepsi & Frekuensi & Persentase & Ket. \\
\hline 1. & Sangat Sesuai & 40 & 42.11 & $\mathrm{SB}$ \\
\hline 2. & Sesuai & 32 & 33.68 & B \\
\hline 3. & Kurang Sesuai & 18 & 18.95 & $\mathrm{~KB}$ \\
\hline 4. & Tidak Sesuai & 5 & 5.26 & $\mathrm{~TB}$ \\
\hline \multicolumn{2}{|r|}{ Jumlah } & 95 & 100 & \\
\hline
\end{tabular}

Sumber: Angket Nomor 4-5.

Tabel $3.2 \mathrm{di}$ atas menggambarkan bahwa metode pembelajaran dosen memiliki dampak dalam bentuk mudah memahami materi pembelajaran 72 orang atau $75.79 \%$ menyatakan setuju, sementara yang tidak setuju 23 orang atau 24.21\%. Dengan demikian secara umum dampak pembelajaran dosen menurut persepsi mahasiswa dipandang mudah memahami materi pembelajaran, namun demikian masih ada mahasiswa yang menyatakan sebaliknya (susah memahai materi pembelajaran). Jika dikonfirmasi berdasarkan kriteria yang telah disusun peneliti, maka didapatkan data $40(42.11 \%)$ memiliki persepsi kategori sangat baik, 32 (33.68\%) memiliki persepsi kategori baik, 18 (18.95\%) memiliki persepsi kategori kurang baik, dan 5 (5.26\%) memiliki persepsi kategori tidak baik.

Persepsi mahasiswa sebagai dampak penerapan metode pembelajaran dalam bentuk efektif mencapai tujuan pembelajaran dapat dilihat melalui Tabel 3.3.

Tabel 3.3 Efektif Mencapai Tujuan Pembelajaran

\begin{tabular}{|c|c|c|c|c|}
\hline No. & Kriteria Persepsi & Frekuensi & Persentase & Ket. \\
\hline 1. & Sangat Sesuai & 39 & 41.05 & SB \\
\hline 2. & Sesuai & 37 & 38.95 & B \\
\hline 3. & Kurang Sesuai & 15 & 15.79 & KB \\
\hline 4. & Tidak Sesuai & 4 & 4.21 & TB \\
\hline \multicolumn{2}{r|}{ Jumlah } & $\mathbf{9 5}$ & $\mathbf{1 0 0}$ & \\
\hline
\end{tabular}

Sumber: Angket Nomor 5.

Tabel 3.3 di atas menggambarkan bahwa metode pembelajaran dosen memiliki dampak dalam bentuk efektif mencapai tujuan pembelajaran 76 orang atau $80 \%$ menyatakan setuju, sementara yang tidak setuju 19 orang atau $20 \%$. Dengan demikian secara umum dampak pembelajaran dosen menurut persepsi mahasiswa dipandang 
efektif mencapai tujuan pembelajaran, namun demikian masih ada mahasiswa yang menyatakan sebaliknya (tidak efektif mencapai tujuan pembelajaran). Jika dikonfirmasi berdasarkan kriteria yang telah disusun peneliti, maka didapatkan data 39 (41.05\%) memiliki persepsi kategori sangat baik, 37 (38.95\%) memiliki persepsi kategori baik, 15 (15.79\%) memiliki persepsi kategori kurang baik, dan 4 (4.21\%) memiliki persepsi kategori tidak baik.

Di samping dampak sebagaimana dijelaskan di atas, maka bentuk lain dari dampak penerapan metode pembelajaran dosen adalah motivasi dan minat belajar, hal ini dijelaskan melalui point selanjutnya (point $\mathrm{b}$ dan point $\mathrm{c}$ ).

b. Motivasi belajar

Motivasi belajar sebagai dampak penerapan metode pembelajaran dosen pada Jurusan Pendidikan Agama Fakultas Tarbiyah dan Keguruan UIN Alauddin Makassar, menurut persepsi mahasiswa dapat dilihat melalui Tabel 3.4.

Tabel 3.4 Dampak Motivasi dalam Belajar

\begin{tabular}{|c|c|c|c|c|}
\hline No. & Kriteria Persepsi & Frekuensi & Persentase & Ket. \\
\hline 1. & Sangat Sesuai & 41 & 43.16 & SB \\
\hline 2. & Sesuai & 33 & 34.74 & B \\
\hline 3. & Kurang Sesuai & 15 & 15.79 & $\mathrm{~KB}$ \\
\hline 4. & Tidak Sesuai & 6 & 6.32 & TB \\
\hline \multicolumn{2}{|r|}{ Jumlah } & 95 & 100 & \\
\hline
\end{tabular}

Sumber: Angket Nomor 9.

Tabel 3.4 di atas menggambarkan bahwa metode pembelajaran dosen memiliki dampak dapat memberikan motivasi belajar mahasiswa 74 orang atau $77.89 \%$ menyatakan setuju, sementara yang tidak setuju 21 orang atau $22.11 \%$. Dengan demikian secara umum dampak pembelajaran dosen menurut persepsi mahasiswa dapat meningkatkan motivasi belajar mahasiswa, namun demikian masih ada mahasiswa yang memiliki persepsi sebaliknya, yakni tidak dapat meningkatkan motivasi belajar mahasiswa. Jika dikonfirmasi berdasarkan kriteria yang telah disusun peneliti, maka didapatkan data $41(43,16 \%)$ memiliki persepsi kategori sangat baik, 33 (34.74\%) memiliki persepsi kategori baik, 15 (15.79\%) memiliki persepsi kategori kurang baik, dan $6(6.32 \%)$ memiliki persepsi kategori tidak baik.

c. Minat

Minat belajar sebagai dampak penerapan metode pembelajaran dosen pada Jurusan Pendidikan Agama Fakultas Tarbiyah dan Keguruan UIN Alauddin Makassar, menurut persepsi mahasiswa dapat dilihat melalui Tabel 3.5. 
Tabel 3.5 Dampak Minat dalam Belajar

\begin{tabular}{|c|c|c|c|c|}
\hline No. & Kriteria Persepsi & Frekuensi & Persentase & Ket. \\
\hline 1. & Sangat Sesuai & 40 & 42.11 & SB \\
\hline 2. & Sesuai & 36 & 37.89 & B \\
\hline 3. & Kurang Sesuai & 13 & 13.68 & $\mathrm{~KB}$ \\
\hline 4. & Tidak Sesuai & 6 & 6.32 & $\mathrm{~TB}$ \\
\hline \multicolumn{2}{|r|}{ Jumlah } & 95 & 100 & \\
\hline
\end{tabular}

Sumber: Angket Nomor 11.

Tabel 3.5 di atas menggambarkan bahwa metode pembelajaran dosen memiliki dampak dapat menarik minat belajar mahasiswa 76 orang atau $80 \%$ menyatakan setuju, sementara yang tidak setuju 19 orang atau 20\%. Dengan demikian secara umum dampak pembelajaran dosen menurut persepsi mahasiswa dapat menarik minat belajar mahasiswa, namun demikian masih ada mahasiswa yang memiliki persepsi sebaliknya, yakni tidak dapat menarik minat belajar mahasiswa. Jika dikonfirmasi berdasarkan kriteria yang telah disusun peneliti, maka didapatkan data $40(42.11 \%)$ memiliki persepsi kategori sangat baik, 36 (37.89\%) memiliki persepsi kategori baik, 13 (13.68\%) memiliki persepsi kategori kurang baik, dan 6 (6.32\%) memiliki persepsi kategori tidak baik.

d. Pembelajaran aktif

Pembelajaran aktif sebagai dampak penerapan metode pembelajaran dosen pada Jurusan Pendidikan Agama Fakultas Tarbiyah dan Keguruan UIN Alauddin Makassar, menurut persepsi mahasiswa dapat dilihat melalui Tabel 3.6.

Tabel 3.6 Dampak dalam Bentuk Menciptakan Suasana Belajar Aktif

\begin{tabular}{|c|c|c|c|c|}
\hline No. & Kriteria Persepsi & Frekuensi & Persentase & Ket. \\
\hline 1. & Sangat Sesuai & 46 & 48.42 & SB \\
\hline 2. & Sesuai & 33 & 34.74 & B \\
\hline 3. & Kurang Sesuai & 9 & 9.47 & $\mathrm{~KB}$ \\
\hline 4. & Tidak Sesuai & 7 & 7.37 & $\mathrm{~TB}$ \\
\hline \multicolumn{2}{|r|}{ Jumlah } & 95 & 100 & \\
\hline
\end{tabular}

Sumber: Angket Nomor 13.

Tabel 3.6 di atas menggambarkan bahwa metode pembelajaran dosen memiliki dampak dapat menciptakan suasana pembelajaran yang aktif 79 orang atau $83.16 \%$ menyatakan setuju, sementara yang tidak setuju 16 orang atau $16.84 \%$. Dengan demikian secara umum dampak pembelajaran dosen menurut persepsi mahasiswa dapat menciptakan suasana belajar yang mengaktifkan mahasiswa, namun demikian masih ada 
mahasiswa yang memiliki persepsi sebaliknya, yakni tidak dapat mengaktifkan mahasiswa dalam belajar. Jika dikonfirmasi berdasarkan kriteria yang telah disusun peneliti, maka didapatkan data $46(48.42 \%)$ memiliki persepsi kategori sangat baik, 33 (34.74\%) memiliki persepsi kategori baik, 9 (9.47\%) memiliki persepsi kategori kurang baik, dan 7 (7.37\%) memiliki persepsi kategori tidak baik.

e. Pembelajaran menarik

Pembelajaran yang menarik sebagai dampak penerapan metode pembelajaran dosen pada Jurusan Pendidikan Agama Fakultas Tarbiyah dan Keguruan UIN Alauddin Makassar, menurut persepsi mahasiswa dapat dilihat melalui Tabel 3.7.

Tabel 3.7 Dampak dalam Bentuk Menciptakan Pembelajaran yang Menarik

\begin{tabular}{|c|c|c|c|c|}
\hline No. & Kriteria Persepsi & Frekuensi & Persentase & Ket. \\
\hline 1. & Sangat Sesuai & 39 & 41.05 & SB \\
\hline 2. & Sesuai & 33 & 34.74 & B \\
\hline 3. & Kurang Sesuai & 16 & 16.84 & KB \\
\hline 4. & Tidak Sesuai & 7 & 7.37 & TB \\
\hline \multicolumn{2}{|r|}{ Jumlah } & 95 & 100 & \\
\hline
\end{tabular}

Sumber: Angket Nomor 10.

Tabel 3.7 di atas menggambarkan bahwa metode pembelajaran dosen memiliki dampak dapat menciptakan suasana pembelajaran yang menarik 72 orang atau $75.79 \%$ menyatakan setuju, sementara yang tidak setuju 23 orang atau $24.71 \%$. Dengan demikian secara umum dampak pembelajaran dosen menurut persepsi mahasiswa dapat menciptakan suasana pembelajaran yang menarik, namun demikian masih ada mahasiswa yang memiliki persepsi sebaliknya, yakni tidak dapat menciptakan suasana belajar yang menarik. Jika dikonfirmasi berdasarkan kriteria yang telah disusun peneliti, maka didapatkan data 39 (41.05\%) memiliki persepsi kategori sangat baik, 33 (34.74\%) memiliki persepsi kategori baik, 16 (16.84\%) memiliki persepsi kategori kurang baik, dan $7(7.37 \%)$ memiliki persepsi kategori tidak baik.

f. Pembelajaran menyenangkan

Pembelajaran yang menyenangkan sebagai dampak penerapan metode pembelajaran dosen pada Jurusan Pendidikan Agama Fakultas Tarbiyah dan Keguruan UIN Alauddin Makassar, menurut persepsi mahasiswa dapat dilihat melalui Tabel 3.8.

Tabel 3.8 Dampak dalam Bentuk Menciptakan Pembelajaran yang Menyenangkan

\begin{tabular}{|c|c|c|c|c|}
\hline No. & Kriteria Persepsi & Frekuensi & Persentase & Ket. \\
\hline 1. & Sangat Sesuai & 44 & 46.32 & SB \\
\hline 2. & Sesuai & 32 & 33.68 & B \\
\hline
\end{tabular}




\begin{tabular}{|c|c|c|c|c|}
\hline 3. & Kurang Sesuai & 16 & 16.84 & $\mathrm{~KB}$ \\
\hline 4. & Tidak Sesuai & 3 & 3.16 & $\mathrm{~TB}$ \\
\hline \multicolumn{2}{|r|}{ Jumlah } & 95 & 100 & \\
\hline
\end{tabular}

Sumber: Angket Nomor 14.

Tabel 3.8 di atas menggambarkan bahwa metode pembelajaran dosen memiliki dampak dapat menciptakan suasana pembelajaran yang menyenangkan 76 orang atau $80 \%$ menyatakan setuju, sementara yang tidak setuju 19 orang atau 20\%. Dengan demikian secara umum dampak pembelajaran dosen menurut persepsi mahasiswa dapat menciptakan suasana pembelajaran yang menyenangkan, namun demikian masih ada mahasiswa yang memiliki persepsi sebaliknya, yakni tidak dapat menciptakan suasana belajar yang menyenangkan. Jika dikonfirmasi berdasarkan kriteria yang telah disusun peneliti, maka didapatkan data $44(46.32 \%)$ memiliki persepsi kategori sangat baik, 32 (33.68\%) memiliki persepsi kategori baik, 16 (16.84\%) memiliki persepsi kategori kurang baik, dan 3 (3.16\%) memiliki persepsi kategori tidak baik.

g. Membangun keakraban sesama mahasiswa

Membangun keakraban sesama mahasiswa sebagai dampak penerapan metode pembelajaran dosen pada Jurusan Pendidikan Agama Fakultas Tarbiyah dan Keguruan UIN Alauddin Makassar, menurut persepsi mahasiswa dapat dilihat melalui Tabel 3.9.

Tabel 3.9 Dampak dalam Bentuk Menciptakan Pembelajaran yang Membangun Keakraban Sesama Mahasiswa

\begin{tabular}{|c|c|c|c|c|}
\hline No. & Kriteria Persepsi & Frekuensi & Persentase & Ket. \\
\hline 1. & Sangat Sesuai & 47 & 49.47 & SB \\
\hline 2. & Sesuai & 24 & 25.26 & B \\
\hline 3. & Kurang Sesuai & 15 & 15.79 & $\mathrm{~KB}$ \\
\hline 4. & Tidak Sesuai & 9 & 9.47 & $\mathrm{~TB}$ \\
\hline \multicolumn{2}{|r|}{ Jumlah } & 95 & 100 & \\
\hline
\end{tabular}

Sumber: Angket Nomor 16.

Tabel 3.9 di atas menggambarkan bahwa metode pembelajaran dosen memiliki dampak dapat membangun keakraban mahasiswa 71 orang atau $74.74 \%$ menyatakan setuju, sementara yang tidak setuju 24 orang atau 25.26\%. Dengan demikian secara umum dampak pembelajaran dosen menurut persepsi mahasiswa dapat membangun suasana keakraban mahasiswa, namun demikian masih ada mahasiswa yang memiliki persepsi sebaliknya, yakni tidak dapat membangun keakraban. Jika dikonfirmasi berdasarkan kriteria yang telah disusun peneliti, maka didapatkan data 47 (49.47\%) memiliki persepsi kategori sangat baik, 24 (25.26\%) memiliki persepsi kategori baik, 15 (15.79\%) memiliki persepsi kategori kurang baik, dan 9 (9.47\%) memiliki persepsi 
kategori tidak baik.

h. Membangun komunikasi positif dengan dosen

Membangun komunikasi positif sebagai dampak penerapan metode pembelajaran dosen pada Jurusan Pendidikan Agama Fakultas Tarbiyah dan Keguruan UIN Alauddin Makassar, menurut persepsi mahasiswa dapat dilihat melalui Tabel 3.10.

Tabel 3.10 Dampak dalam Bentuk Menciptakan Pembelajaran yang Membangun Komunikasi Positif Mahasiswa dengan Dosen

\begin{tabular}{|c|c|c|c|c|}
\hline No. & Kriteria Persepsi & Frekuensi & Persentase & Ket. \\
\hline 1. & Sangat Sesuai & 52 & 54.74 & SB \\
\hline 2. & Sesuai & 25 & 26.32 & B \\
\hline 3. & Kurang Sesuai & 11 & 11.58 & KB \\
\hline 4. & Tidak Sesuai & 7 & 7.37 & TB \\
\hline \multicolumn{2}{r|}{ Jumlah } & $\mathbf{9 5}$ & $\mathbf{1 0 0}$ & \\
\hline
\end{tabular}

Sumber: Angket Nomor 17.

Tabel 3.10 di atas menggambarkan bahwa metode pembelajaran dosen memiliki dampak dapat membangun komunikasi positif antara mahasiswa dengan dosen 77 orang atau $81.05 \%$ menyatakan setuju, sementara yang tidak setuju 18 orang atau $18.95 \%$. Dengan demikian secara umum dampak pembelajaran dosen menurut persepsi mahasiswa dapat membangun komunikasi positif antara mahasiswa dengan dosen, namun demikian masih ada mahasiswa yang memiliki persepsi sebaliknya, yakni tidak dapat membangun komunikasi yang positif. Jika dikonfirmasi berdasarkan kriteria yang telah disusun peneliti, maka didapatkan data 52 (54.74\%) memiliki persepsi kategori sangat baik, $25(26.32 \%)$ memiliki persepsi kategori baik, 11 (11.58\%) memiliki persepsi kategori kurang baik, dan 7 (7.37\%) memiliki persepsi kategori tidak baik.

i. Membangun sikap religious mahasiswa

Membangun sikap religious sebagai dampak penerapan metode pembelajaran dosen pada Jurusan Pendidikan Agama Fakultas Tarbiyah dan Keguruan UIN Alauddin Makassar, menurut persepsi mahasiswa dapat dilihat melalui Tabel 3.11.

Tabel 3.11 Dampak dalam Bentuk Menciptakan Pembelajaran yang Membangun Sikap Religius Mahasiswa

\begin{tabular}{|c|c|c|c|c|}
\hline No. & Kriteria Persepsi & Frekuensi & Persentase & Ket. \\
\hline 1. & Sangat Sesuai & 49 & 51.58 & SB \\
\hline 2. & Sesuai & 27 & 28.42 & B \\
\hline 3. & Kurang Sesuai & 9 & 9.47 & KB \\
\hline 4. & Tidak Sesuai & 10 & 10.53 & TB \\
\hline
\end{tabular}




\begin{tabular}{|c|c|c|c|}
\hline Jumlah & $\mathbf{9 5}$ & $\mathbf{1 0 0}$ & \\
\hline
\end{tabular}

Sumber: Angket Nomor 18.

Tabel 3.11 di atas menggambarkan bahwa metode pembelajaran dosen memiliki dampak dapat membangun sikap religius mahasiswa 76 orang atau $80 \%$ menyatakan setuju, sementara yang tidak setuju 19 orang atau 20\%. Dengan demikian secara umum dampak pembelajaran dosen menurut persepsi mahasiswa dapat membangun sikap religious mahasiswa, namun demikian masih ada mahasiswa yang memiliki persepsi sebaliknya, yakni tidak dapat membangun sikap religius. Jika dikonfirmasi berdasarkan kriteria yang telah disusun peneliti, maka didapatkan data 49 (51.58\%) memiliki persepsi kategori sangat baik, 27 (28.42\%) memiliki persepsi kategori baik, 9 (9.47\%) memiliki persepsi kategori kurang baik, dan 10 (10.53\%) memiliki persepsi kategori tidak baik.

j. Membangun sikap sosial mahasiswa

Membangun sikap sosial mahasiswa sebagai dampak penerapan metode pembelajaran dosen pada Jurusan Pendidikan Agama Fakultas Tarbiyah dan Keguruan UIN Alauddin Makassar, menurut persepsi mahasiswa dapat dilihat melalui Tabel 3.12.

Tabel 3.12 Dampak dalam Bentuk Menciptakan Pembelajaran yang Membangun Sikap Sosial Mahasiswa

\begin{tabular}{|c|c|c|c|c|}
\hline No. & Kriteria Persepsi & Frekuensi & Persentase & Ket. \\
\hline 1. & Sangat Sesuai & 53 & 55.79 & SB \\
\hline 2. & Sesuai & 32 & 33.68 & B \\
\hline 3. & Kurang Sesuai & 10 & 10.53 & $\mathrm{~KB}$ \\
\hline 4. & Tidak Sesuai & 0 & 0.00 & $\mathrm{~TB}$ \\
\hline \multicolumn{2}{|r|}{ Jumlah } & 95 & 100 & \\
\hline
\end{tabular}

Sumber: Angket Nomor 19.

Tabel 3.12 di atas menggambarkan bahwa metode pembelajaran dosen memiliki dampak dapat membentuk sikap sosial mahasiswa 85 orang atau $89.47 \%$ menyatakan setuju, sementara yang tidak setuju 10 orang atau $10.53 \%$. Dengan demikian secara umum dampak pembelajaran dosen menurut persepsi mahasiswa dapat membangun sikap sosial mahasiswa, namun demikian masih ada mahasiswa yang memiliki persepsi sebaliknya, yakni tidak dapat membentuk sikap sosial. Jika dikonfirmasi berdasarkan kriteria yang telah disusun peneliti, maka didapatkan data $53(55.79 \%)$ memiliki persepsi kategori sangat baik, 32 (33.68\%) memiliki persepsi kategori baik, 10 (10.53\%) memiliki persepsi kategori kurang baik, dan $0(0 \%)$ memiliki persepsi kategori tidak baik. 
k. Membangun sikap emosional mahasiswa

Membangun sikap emosional mahasiswa sebagai dampak penerapan metode pembelajaran dosen pada Jurusan Pendidikan Agama Fakultas Tarbiyah dan Keguruan UIN Alauddin Makassar, menurut persepsi mahasiswa dapat dilihat melalui Tabel 3.13.

Tabel 3.13 Dampak dalam Bentuk Menciptakan Pembelajaran yang

Membangun Sikap Emosional Mahasiswa

\begin{tabular}{|c|c|c|c|c|}
\hline No. & Kriteria Persepsi & Frekuensi & Persentase & Ket. \\
\hline 1. & Sangat Sesuai & 28 & 29.47 & $\mathrm{SB}$ \\
\hline 2. & Sesuai & 38 & 40.00 & B \\
\hline 3. & Kurang Sesuai & 22 & 23.16 & $\mathrm{~KB}$ \\
\hline 4. & Tidak Sesuai & 7 & 7.37 & $\mathrm{~TB}$ \\
\hline \multicolumn{2}{|r|}{ Jumlah } & 95 & 100 & \\
\hline
\end{tabular}

Sumber: Angket Nomor 20.

Tabel 3.13 di atas menggambarkan bahwa metode pembelajaran dosen memiliki dampak dapat membentuk sikap emosional mahasiswa 66 orang atau $69.47 \%$ menyatakan setuju, sementara yang tidak setuju 29 orang atau 30.53\%. Dengan demikian secara umum dampak pembelajaran dosen menurut persepsi mahasiswa dapat membangun sikap emosional mahasiswa, namun demikian masih ada mahasiswa yang memiliki persepsi sebaliknya, yakni tidak dapat membentuk sikap emosional. Jika dikonfirmasi berdasarkan kriteria yang telah disusun peneliti, maka didapatkan data 28 (29.47\%) memiliki persepsi kategori sangat baik, 38 (40\%) memiliki persepsi kategori baik, 22 (23.16\%) memiliki persepsi kategori kurang baik, dan 7 (7.37\%) memiliki persepsi kategori tidak baik.

\section{KESIMPULAN}

Dampak penerapan metode pembelajaran dosen pada Jurusan Pendidikan Agama Islam Fakultas Tarbiyah dan Keguruan UIN Alauddin Makassar dalam bentuk: (a) mudah mencapai tujuan pembelajaran 62 orang atau $65.26 \%$ yang menyatakan setuju (kategori Baik); (b) mudah memahami materi pembelajaran 72 orang atau $75.79 \%$ menyatakan setuju (kategori Baik); (c) efektif mencapai tujuan pembelajaran 76 orang atau 80\% menyatakan setuju (kategori Sangat Baik); (d) meningkatkan motivasi belajar mahasiswa 74 orang atau $77.89 \%$ menyatakan setuju (kategori Baik); (e) meningkatkan minat belajar mahasiswa 76 orang atau 80\% menyatakan setuju (kategori Baik); (f) menciptakan suasana pembelajaran yang aktif 79 orang atau $83.16 \%$ menyatakan setuju (kategori Sangat Baik); (g) menciptakan suasana pembelajaran yang menarik 72 orang atau $75.79 \%$ (kategori Baik); (h) menciptakan suasana pembelajaran yang 
menyenangkan 76 orang atau 80\% menyatakan setuju (kategori Baik); (i) membangun keakraban sesame mahasiswa 71 orang atau $74.74 \%$ menyatakan setuju (kategori Baik); (j) membangun komunikasi positif antara mahasiswa dengan dosen 77 orang atau 81.05\% menyatakan setuju (kategori Sangat Baik); (k) membangun sikap religius mahasiswa 76 orang atau 80\% menyatakan setuju (kategori Baik); (1) membentuk sikap sosial mahasiswa 85 orang atau $89.47 \%$ menyatakan setuju (kategori Sangat Baik); (m) membentuk sikap emosional mahasiswa 66 orang atau $69.47 \%$ menyatakan setuju (kategori Baik).

\section{DAFTAR PUSTAKA}

Calhoun, JF \& Acocella, J.R. 1995. Psychology of Adjusment and Human Relationship. New York: Mc Graw Hill, Inc.

Darajat, Zakiyah, 2011, Metodik Khusus Pengajaran Agama Islam, Jakarta: Bumi Aksara.

Dimyati dan Mudjiono. 2006. Belajar dan Pembelajaran. Jakarta: Rineke Cipta.

Dirgagunarsa, Singgih. 1992. Pengantar Psikologi. Jakarta: Mutiara Sumber Widya.

E. Mulyasa. (2006). Menjadi Guru Profesional Menciptakan Pembelajaran Kreatif dan Menyenangkan. Bandung: Remaja Rosdakarya Offset.

Gerlach dan Ely (1971). Teaching \& Media: A Systematic Approach. Second Edition, by V.S. Gerlach \& D.P. Ely, 1980, Boston, MA: Allyn and Bacon. Copyright 1980 by Pearson Education.

Gulo, Dali. 1982. Kamus Psikologi. Bandung: Tonis.

Hannessy, Bernard. 1981. Public Opinion. Wadsworth, Inc.

Hardy, Malcolm \& Steve Heyes. 1988. Pengantar Psikologi, Alih Bahasa Soenardji. Jakarta: Erlangga.

Morgan, Clifford T. 1961. Introduction to Psychology, Second Edition. Toronto, London: McGraw Hill Company, Inc., N.Y.

Muhadjir, Noeng. 1992. Pengukuran Kepribadian Telaah Konsep dan Teknik Penyusunan Tes Psikomotorik dan Skala Sikap. Yogyakarta: Rake Sarasin.

Rakhmat, Jalaluddin. 1991. Metode Penelitian Komunikasi. Bandung: PT Remaja Rosdakarya.

Ramayulis. 2014. Metodologi Pendidikan Agama Islam. Jakarta: Kalam Mulia. 
Sardiman, A.M. 1986. Interaksi dan Motivasi Belajar Mengajar. Jakarta: Rajawali.

Sudjana. (2005). Metode Statistika. Bandung: Tarsito.

Sobur, Alex. 2011. Psikologi Umum. Bandung Pustaka Setia.

Pate Russel; Bruce Mc Clenghan ang Robert Rotella (1993) Dasar-dasar ilmiah kepelatihan.Terjemahan oleh Drs.Kasiyo Dwi jowinoto.Ms. Semarang: IKIP Semarang Press.

Wahidmurni, dkk. 2010. Evaluasi Pembelajaran. Yogyakarta: Nuha Litera.

Warsito. 2006. Bunga Rampai Keberhasilan Guru dalam Pembelajaran (SMA, SMK, dan SLB). Jakarta: Depdiknas.

Zulfebriges. 1995. Pengaruh Persepsi terhadap Komunikasi Interpersonal. Makalah, Disampaikan pada Seminar Intern Dosen FIK Universitas Islam Bandung. 